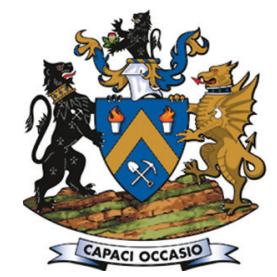

Affiliation:

${ }^{1}$ CSIR Mining Cluster, South

Africa.

2University of Johannesburg,

South Africa.

Correspondence to:

J.L. Pelders

Email:

JHodgskiss@csir.co.za

Dates:

Received: 19 Nov. 2020

Revised: 1 Jul. 2021

Accepted: 8 Jul. 2021

Published: August 2021

\section{How to cite:}

Pelders, J.L., Magweregwede, F., and Rupprecht, S.M. 2021

Optimization of shift cycles in the

South African mining sector.

Journal of the Southern African

Institute of Mining and Metallurgy,

vol. 121 , no. 8 , pp. 427-436

DOI ID:

http://dx.doi.org/10.17159/2411-

9717/1428/2021

ORCID:

J.L. Pelders

http://orcid.org/0000-0003-

4671-1951

F. Magweregwede

https://orcid.org/0000-0002-

4824-2266

S.M. Rupprecht

https://orcid.org/0000-0003-

2462-2819

\title{
Optimization of shift cycles in the South African mining sector
}

\author{
J. Pelders' ${ }^{1}$, F. Magweregwede ${ }^{1}$, and S.M. Rupprecht ${ }^{2}$
}

\begin{abstract}
Synopsis
Increased depths of conventional gold and platinum mines, longer travelling times as working places move further from the shaft, and ancillary activities taking place in the mining cycle reduce the useable time spent at the workface. Current shift lengths of 8 hours 20 minutes may no longer be adequate to complete required mining activities. The impact of mineworker commuting times on shift work is also not well understood. The aim of this research was to draft a framework to optimize shift cycles in order to maximize productivity, health, safety, and wellness in the South African mining sector. The framework was informed by a review of the literature, case studies at a local gold mine and platinum mine, and a workshop with industry experts. The findings indicate potential advantages of extended shift lengths and continuous operations, such as improved productivity, asset utilization, and employee morale. However, concerns included fatigue and the associated safety hazards, particularly when working longer shifts, night shifts, and numerous consecutive shifts. Job demands, personal factors, and commuting times are further considerations when scheduling shifts. The ideal shift system for the mining sector should holistically consider and balance operational requirements, health and safety, and employees' and their families' requirements, and suit the unique needs of each operation. Changes in shift cycles will require a structured change management process, which involves all stakeholders, and could help to enhance the viability of the South African mining sector.
\end{abstract}

\section{Keywords}

ancillary activities, continuous operations, fatigue, occupational health and safety (OHS), productivity, travelling time.

\section{Introduction}

The productivity of most conventional South African underground gold and platinum mines is declining, operational costs are increasing, and profit margins are shrinking, while health, safety, social, and environmental challenges are present (Neingo and Tholana, 2016; Singh, 2017). Many narrow-reef gold and platinum mines in the country are increasing in depth to reach new deposits, resulting in longer travelling times, rising costs, reduced profits, and heightened risks (Deloitte, 2014; Jacobs and WebberYoungman, 2017; Minerals Council South Africa, 2018; Rupprecht, 2018a; Singh, 2017). The increased travelling times, along with additional ancillary activities taking place in the mining cycle, reduce time spent at the workface, and might hinder the attainment of a daily conformant blast (Gumbie, 2018). Previous research has indicated that mandatory shift lengths of 8 hours 20 minutes may no longer be adequate to complete the required mining activities (Rupprecht, 2018b). Increased shift lengths and the adoption of close-to-continuous operations (CONOPs) could help to address these challenges (Lazare, 2013). Factors affecting occupational health and safety (OHS) and worker wellbeing also need to be considered in relation to shift work. For example, the effects of worker travelling times from home to the stope face and the impacts of working conditions on worker fatigue are not well understood (Gumbie, 2018).

The purpose of the project was to draft a framework to assist mines to optimize shift cycles in order to maximize productivity, OHS performance, and employee wellness. The research assessed potential challenges in different activities in relation to on available face time, and feasible alternative shift cycles in the South African mining industry. Additionally, we examined the effects of commuting times, particularly regarding fatigue. The project was informed by a review of the literature, two case studies conducted in the South African mining industry, and a workshop with technical experts. The 


\section{Optimization of shift cycles in the South African mining sector}

project was commissioned by the South African Mining Research, Development and Innovation (SAMERDI) strategy's Longevity of Current Mines (LoCM) programme of the Mandela Mining Precinct (Pelders et al., 2019).

\section{Literature review}

\section{Shift work}

Shift work is required in many industries, including mining, and allows for longer hours of operation (Baulk et al., 2009). Shift work refers to 'an organisation of work where workers succeed each other at the same workplace while performing similar operations at different times of the day thus allowing longer hours of operation than feasible for a single worker' (Department of Mineral Resources, 2014, p. 36). Continuous shift work refers to operations that run 24 hours per day, seven days per week, throughout the year (Department of Labour, 1998). For this research, the terms 'continuous operations' (CONOPS) and 'full calendar operations' (FULCO) are used interchangeably. Numerous shift cycles are used in industry, and typically involve three 8-hour shifts or two 12-hour shifts, while some mines in South Africa operate two 10-, 10.5-, or 11-hour shifts (Baulk et al., 2009; Theron, 2014).

Conflicting findings regarding the pros and cons of different shift lengths are evident in the literature and are likely contextdependent. However, potential advantages of extended (e.g. 12hour) shift lengths might include improved productivity, better asset utilization, improved communication at shift changeovers, reduced sick leave, and improved employee morale (Baker, Heiler, and Ferguson, 2003; Stenzel, 2002). The use of 12-hour shifts results in compressed working weeks, which allows for longer periods of time off for social and domestic interaction and leisure, and a reduction in total commuting time (Baulk et al., 2009). Meanwhile, disadvantages of extended shifts could include fatigue, impaired performance, and increased rate of incidents (Baker, Heiler, and Ferguson, 2003; Bates, 2009; Baulk et al., 2009; Spencer, Robertson, and Folkard, 2006). As such, shift cycles should be designed to minimize fatigue, optimize productivity and OHS performance, and improve mine viability (Ngobese, 2017; Pickering, du Plessis, and Annandale, 2010; Smith et al., 1998; Stenzel, 2002).

\section{Legal requirements and guidelines}

Shift work and working hours are subject to regulations. Key pieces of legislation covering shift rostering at mining operations in South Africa include the following.

> Occupational Health and Safety Act (OHSA, Act No. 85 of 1993) (Department of Labour, 1993)

> Mine Health and Safety Act (MHSA, Act No. 29 of 1996) (Department of Mineral Resources, 1996)

> Basic Conditions of Employment Act (BCEA, Act No. 75 of 1997) (Department of Labour, 1997)

> Code of Good Practice on the Arrangement of Working Time (Department of Labour, 2017);

> Guideline for Mandatory Code of Practice (COP) for RiskBased Fatigue Management at Mines (Department of Mineral Resources, 2014).

Employers are required to evaluate work schedules to ensure that the health and safety of employees will not be at risk. The MHSA No. 29 of 1996 and OHSA No. 85 of 1993 require employers to conduct a risk assessment, implement measures to eliminate or control identified hazards, conduct medical surveillance concerning those hazards for employees, and train and inform employees about the risks and controls. The BCEA No. 75 of 1997 considers factors such as ordinary hours of work, overtime, compressed working weeks, averaging the hours of work, meal intervals, daily and weekly rest periods, and pay for work on Sundays, night work and public holidays. Exemptions in terms of collective agreements can be provided, subject to provisions.

The Code of Good Practice on the Arrangement of Working Time relates to shift work, night work, and rest periods during working time, and provides information about the impact of working time arrangements on the health, safety, and family responsibilities of employees (Department of Labour, 1997, 1998). The Guideline for a Mandatory COP for Risk-Based Fatigue Management at Mines assists employers to prepare a risk-based COP on fatigue management (Department of Mineral Resources, 2014).

\section{Fatigue and other impacts of shift cycles on people}

Shift work is associated with disturbed sleep, fatigue, reduced alertness and performance, occupational accidents and incidents, health problems, negative effects on social and domestic activities, and impaired mood (Baulk et al., 2009; Greubel et al., 2016; Härmä et al., 2018; Kalmbach et al., 2018). These risks could lead to economic losses resulting from increased sick leave and staff turnover rates (Greubel et al., 2016; Jacobsen and Fjeldbraaten, 2018). Absenteeism has been attributed to lengthy work hours, fatigue resulting from shift length and/or environmental conditions in the stope, and commuting to and from home (Rupprecht, 2018b).

Shift work, or work performed at unusual times, results in misalignment of the circadian rhythm (or 'body clock') with activities and sleep schedules, which contributes to fatigue or sleepiness at work (Department of Mineral Resources, 2014; Greubel et al., 2016; Kalmbach et al., 2018; Schutte, 2010a). Shift cycle characteristics that are associated with the risk of fatigue and incidents include the time of day, direction and speed of shift rotation, consecutive hours on duty, number of consecutive shifts, breaks between work periods, and rest breaks during work. In particular, factors associated with higher risk of fatigue and accidents include early morning or night shift work, backward rotating shifts, long shift durations (e.g. 12-hour shifts), too many consecutive shifts, a lack of rest breaks, and excessive overtime and on-call work (Bates, 2009; Department of Mineral Resources, 2014; Greubel et al., 2016; Härmä et al., 2018; Kalmbach et al., 2018; Spencer, Robertson, and Folkard, 2006; Theron, 2014).

As a result of these circadian and sleep disruptions, fatigue is an inherent hazard in shift work and is a causal or contributing factor in many occupational incidents in the mining industry (Hodgskiss et al., 2015; Pelders and Nelson, 2019; Schutte, 2010a; Theron, 2014). Fatigue results in reduced performance and productivity, impaired alertness, increased error rates, and can also result in medical and psychological problems such as heart disease, hypertension, diabetes, digestive problems, anxiety and depression (Bates, 2009; Department of Mineral Resources, 2014; Pelders and Nelson, 2019; Pfeifer, 2017; Schutte, 2010a; Theron, 2014). Numerous factors can contribute to fatigue in addition to shift work, including the job demands (e.g. stress), work environment (e.g. lighting, heat, and humidity), medical 


\section{Optimization of shift cycles in the South African mining sector}

conditions, psychological factors, lifestyle and activities outside of work, nutrition, demographics, socio-economic status, living conditions, and commuting times (Department of Mineral Resources, 2014; Pelders and Nelson, 2019; Schutte, 2010a; Theron, 2014).

Work factors associated with high risk of fatigue and accidents during shift work include heavy physical work, sustained effort, complex tasks, critical monitoring tasks, or repetitive and monotonous tasks (Baulk et al., 2009; Department of Labour, 1997; Department of Mineral Resources, 2014). Temperature extremes, excessive noise, work stress, poor ergonomic design of workstations and equipment, and long walking distances in underground workplaces can also contribute to fatigue (Department of Mineral Resources, 2014; Hodgskiss et al., 2015; Neingo and Tholana, 2016).

Lifestyle factors, such as activities outside of work and family commitments, poor diet or nutrition, a lack of exercise, as well as drug and alcohol abuse, can also contribute to fatigue (Hodgskiss et al., 2015; Pelders and Nelson, 2019; Department of Mineral Resources, 2014; Theron, 2014). Shift work can prevent workers from completing personal chores and can result in desynchronization with social participation and increased risk of poor work-life balance (Brown et al., 2010; Greubel et al., 2016; Rupprecht, 2018b). Additionally, factors such as sleep routines, maintaining healthy diets, and exercise and recreational activities can affect how employees adapt to shift work (Department of Labour, 1998; Department of Mineral Resources, 2014).

Commuting times, including time to travel from home to the mine and back again, and month-end travelling to and from labour-sending areas, can have an impact on health, safety, absenteeism, and fatigue outcomes (Brovko et al., 2018; Pfeifer, 2017; Rupprecht, 2018b; Sanqu, 2016). Workers with longer commutes have been shown to obtain less sleep during the work week, report higher levels of sleepiness, be less productive at work, and have significantly higher absenteeism rates (Hodgskiss et al, 2015; Pfeifer, 2017; van Ommeren and Gutierrez-i-Puigarnau, 2009). Theron (2014), for example, noted that mine employees' days commonly start at 3 am to catch public transport in order to start work at $6 \mathrm{am}$, and that they might only return home around $5 \mathrm{pm}$. These commutes limit the time available for workers to attend to household responsibilities and to sleep (Hodgskiss et al., 2015; Pelders and Nelson, 2019; Theron, 2014). Previous research conducted across eight operations in the South African mining industry revealed that over half of the sample of 875 participating mineworkers usually obtained less than 6 hours of sleep in the 24 hours before a work shift, and $31 \%$ reported having occasionally fallen asleep at work (Hodgskiss et al., 2015). Although this sample was not fully representative of the South African mining industry, it incorporated participants from the gold, platinum, coal, diamond, and manganese sectors and was considered to provide a basic indication of the levels of sleep obtained and fatigue among mineworkers in South Africa.

\section{Productivity and operational requirements}

Over the past few years, productivity in narrow-reef hard-rock underground gold and platinum group metal (PGM) mines has been declining due to a number of reasons, including additional safety requirements (e.g. nets), labour unrest, greater mining depth, and increasing working distance from the shaft. Most narrow-reef hard-rock underground gold and PGM mines utilize labour-intensive conventional drill-and-blast mining methods, requiring a re-entry period of between one and four hours after blasting prior to commencement of the subsequent shift (Brake, 2015). The literature study revealed that the standard current shift length of 8 hours 20 minutes is no longer adequate to complete most of the mining tasks in a single shift at most conventional underground mines (Lazare, 2013; Rupprecht, $2018 b)$. The available face time is increasingly becoming marginal due to a number of factors such as increasing travelling times as mines are getting deeper and working faces are progressing further from existing shafts, unauthorized breaks due to lack of discipline, early work stoppages and late shift starts due to activities such as meetings, safety talks, early entry examinations, and risk assessments (Neingo and Tholana, 2016). Other factors that affect labour productivity include prevailing working environmental conditions (such as temperature, humidity, and stoping width), equipment availability, competence and skills of the workforce, workforce efficiency, workforce availability and work ethic within the workforce (Aljuhani, 2002; Neingo and Tholana, 2016; Roussos, 1996).

Productivity in conventional underground gold and PGM mines could be improved through optimization of shift cycles, ensuring the availability of the right-sized workforce to complete all the required tasks within the allotted time (Lazare, 2013; Neingo and Cawood, 2014; Rupprecht, 2016 and 2018b). In order to attain all planned conformant blasts, sufficient time should be allowed for travelling, execution and completion of work, and other ancillary tasks (Rupprecht et al., 2001). Timemotion studies conducted during the Sindisa project were used to identify major ancillary activities that caused delays in the mine production system (Table I). In order to attain an optimal mine production system, a systems thinking approach, aiming to optimize the shift cycles together with other components of system, should be adopted. The majority of the identified delays could be mitigated through good practices such as proper planning, good work organization, efficient communication strategies, and sound maintenance practices. Interventions that could be put in place to improve available face time include reduction of travelling times through efficient personnel transportation systems, longer shifts, and technology solutions to expedite completion of ancillary activities such as early entry examination, barring, support, and risk assessments (Rupprecht, 2016).

The Sindisa Gold project was initiated in 2011 by the Minerals Council South Africa (MCSA) in collaboration with mining companies and organized labour, to explore opportunities for optimizing utilization of mine assets. For the purpose of this article, mine assets include ore reserves, plant, equipment, and machinery. The Sindisa Gold project envisaged optimizing asset utilization through practices such as increasing the number of production days per annum, attaining more planned conformant blasts, and ensuring the availability of mineable ground (including a contingency) all the time (Lazare, 2013). Optimum utilization of labour was to be achieved by increasing the number of production days per annum through adoption of close-toCONOPs, with shift lengths not exceeding 12 hours crush-tocrush (Lazare, 2013). Critical enablers of the process include co-creation of the shift cycles with all stakeholders (including the workforce), sufficient consultation and engagement witj all key stakeholders, and ensuring that the new shift schedules do not violate any legal requirements (Lazare, 2013). 


\section{Optimization of shift cycles in the South African mining sector}

Table I

Examples of delays in ancillary activities in the mining cycle (Lazare, 2013)

\begin{tabular}{|c|c|}
\hline Category of activity & Examples of delays \\
\hline Cleaning cycle-related tasks & $\begin{array}{ll}\text { - } & \text { Locomotive and hopper derailments } \\
\text { - } & \text { Waiting for the crew at the face (late arrivals) } \\
\text { - } & \text { Repairing mechanical loader hoses } \\
\text { - } & \text { Waiting for loco to fetch hopper } \\
\text { - } & \text { Congestion at the tip } \\
\text { - } & \text { Loader derailment } \\
\text { - } & \text { Air coupling came loose } \\
\text { - } & \text { Fixing fishplate } \\
\text { - } & \text { No compressed air } \\
\text { - } & \text { Waiting for support crew } \\
\text { - } & \text { Work stopped due to temperature and ventilation challenges }\end{array}$ \\
\hline Drilling and supporting cycle-related tasks & $\begin{array}{ll}\text { - } & \text { Ventilation interruptions in all the operations } \\
\text { - } & \text { Repaiting for equipment } \\
\text { - } & \text { Replacement of hydraulic pipes } \\
\text { - } & \text { Briefing on safety } \\
\text { - } & \text { Waiting for methanometer } \\
\text { - } & \text { Barring rock from face } \\
\text { - } & \text { Waiting for previous crew to finish } \\
\text { - } & \text { Waiting for drill rigs } \\
\text { - } & \text { Drill bit stuck / replaced } \\
\text { - } & \text { Power outage } \\
\text { - } & \text { Miner and shift boss talks with the team } \\
\text { - } & \text { Waiting for miner } \\
\text { - } & \text { Drill rig with only one boom } \\
\text { - } & \text { Adjusting motors }\end{array}$ \\
\hline
\end{tabular}

\section{Methods}

Two case studies were conducted at mine sites in South Africa. Data was collected at one platinum mine and one gold mine in April and August 2019, respectively. These mines are not representative of the South African mining sector, but provide examples of aspects that are impacted by the design of shift schedules in the industry, in the local context. Convenience sampling was used to identify potential mine sites, with input and understanding from experts in the field, and the sites were selected based on permissions received to collect data. Data was collected from individuals at each mine who had an in-depth knowledge of the operation and access to required information, including human resources (HR), mine planning, and production personnel.

This was a mixed methods study, as both qualitative and quantitative data was gathered. Qualitative data was obtained in interviews and focus group discussions held with the participants. The discussion guides included open-ended questions relating to shift cycles, ancillary activities, face time, travelling times, work conditions, resources, and fatigue. Quantitative data was provided by the mines. This data included the shift rosters and shaft schedules, planned versus actual bankto-bank times, productivity, health, and safety data, and shift activity durations, where available. The data was captured into an electronic format for analysis. Thematic analysis was used to analyse the qualitative data, and themes from the data were coded and summarized. Basic statistical analyses were conducted on quantitative data. Selected shift cycles were analysed using the Health and Safety Executive (HSE) Fatigue and Risk Index calculator. A framework for optimizing shift cycles in the South African mining industry was drafted, based on the results.

A workshop was held following data collection and analysis to present and discuss the findings from this project, and to gain technical input into the draft framework. The workshop was held at the Mandela Mining Precinct on 25 October 2019. The participants included representatives from mining companies, research partners, and the SAMERDI programme. Feedback received from the stakeholders was used to update and refine the draft framework, and to identify future research topics. Engagement with further stakeholders, including labour representatives, will be required before finalization of the shift cycle guidelines for industry.

Ethics approval for the project was granted by the CSIR Research Ethics Committee (reference number: 239/2017).

\section{Results}

\section{Case study 1}

The participating platinum mine is located in the Bushveld Complex in Mpumalanga Province, South Africa. It operates underground at depths of between $50 \mathrm{~m}$ and $850 \mathrm{~m}$, using low-profile mechanized board-and-pillar mining. The mine was classified as a 'hot' mine (wet bulb temperature: $\geq 27.5^{\circ} \mathrm{C}$ ) (Schutte, 2010b), while the work performed was not considered labour-intensive. The mine operated continuously and, in general, the implementation of CONOPs at this mine was considered successful.

The mine operated seven days per week, throughout the year, except for certain public holidays and over the Christmas period. Two 10-hour production shifts operated each day, using a 5D 5N 50 roster (where $\mathrm{D}=$ day shift, $\mathrm{N}=$ night shift, and $\mathrm{O}=$ day off). The start and end times for the day and night shifts were $07 \mathrm{~h} 00$ to $17 \mathrm{~h} 00$ and $20 \mathrm{~h} 00$ to $06 \mathrm{~h} 00$, respectively. However, different documents from the mine showed discrepancies in the official shift start and end times. Other shift cycles that were used at the mine were 4D $404 \mathrm{~N} 40$ shifts (e.g. for essential services and at the plant), and straight shifts, which operated from Monday to 


\section{Optimization of shift cycles in the South African mining sector}

Friday, and only during the day. The mine had 341 production days per year. Employees on CONOPs worked an average of 243 shifts each per year. Maintenance took place in each level every two weeks during day shifts.

During the 10-hour shifts worked by CONOPs employees, approximately 7 hours were spent at the workface. The average travelling time to the face was 30 to 40 minutes, but reached up to 2 hours depending on location in the operation. The longest travelling distance was approximately $2.5 \mathrm{~km}$. The drilling time was approximately 2.5 hours per face. Two spare panels were available to allow for redundancy. Drilling, supporting, and cleaning could extend throughout the shift, as work could continue at another panel once one was completed. Two blasts per day were planned, and the re-entry period was approximately 1 hour. The overall rate of lost blasts for the year to date was $20 \%$, with breakdowns, labour shortages, and service days among the causes.

An analysis was conducted of the number of hours that mining crews spent underground during the previous seven days. The average number of underground hours worked ranged from 6 hours 35 minutes to 8 hours 23 minutes. In general, the night shift underground hours were longer than the day shift hours. Results of face time studies conducted at the mine in 2011 were also assessed, for which average face times of around 7.5 hours were reported. In levels with the longest horizontal travel distances, differences between collar-to-collar and face times ranged from 49 to 98 minutes. Ancillary activities that workers conducted upon arriving at the mine included the collection of lamps and gas detection instruments; queuing for and travelling on chairlifts; walking to (and from) the waiting place; safety and waiting place meetings; and travelling to and from the workface.

The commuting distances for workers ranged from approximately $4 \mathrm{~km}$ to $70 \mathrm{~km}$. Mine buses were available to transport workers to and from the surrounding communities. From an analysis of the pick-up and drop-off times of the mine buses, it was estimated that an employee with a commuting time of 1 hour between home and work, who works 10-hour shifts, had 11 hours available for personal activities and sleep during each workday. This time allowed for the additional half hour between transport arrival/departure and working times, but excluded the time between leaving home and arriving at the transport pick-up point and waiting for the transport to arrive.

The fatality frequency rate at the time of the assessment was 0.00 and the lost-time injury frequency rate was 0.5 (per 200000 shifts worked). The average turnover rate at the mine was $0.5 \%$, and a large portion of the workforce had been at the mine since the operation commenced. The absenteeism rate was considered by the mine management to be relatively low compared to other mines. The average rate of sick leave ranged from $3.5 \%$ to $4.5 \%$, and the average annual and other leave ranged from $7 \%$ to $13.5 \%$ for the previous three months.

\section{Case study 2}

The second case study site was a fully mechanized gold mine in Gauteng Province, South Africa. The mine operated underground at depths of $3000 \mathrm{~m}$. The average wet bulb temperature in the workplaces was $27.5^{\circ} \mathrm{C}$. The mine used CONOPs arrangements. Changes to the shift systems at the mine had been made to improve productivity and to better suit current conditions. The changes involved extension of the shifts and reducing the number of consecutive shifts worked. Improvements in production, maintenance, and safety were reported as a result of the shift changes. However, the cited disadvantages were higher absenteeism and fatigue.

The mining production teams, and some engineering personnel, operated using $4 \times 3$ (or $4 \times 4$ ) shifts (4D $404 \mathrm{~N} 40$ ) that were 11.5 hours long. A maintenance shift was incorporated into this roster, such that three production shifts and one maintenance shift took place in the cycle. The reported clock-in and clock-out times for the day shift were $05 \mathrm{~h} 45$ and $17 \mathrm{~h} 35$, and $17 \mathrm{~h} 40$ and $05 \mathrm{~h} 35$ for the night shift. As with the other case study, slight discrepancies between shift times from different sources were evident, and it was not clear when employees were required to arrive at work versus when they clocked in at the shaft. Production could take place 351 days per year. An agreement was negotiated whereby workers would work for six of the 12 national public holidays and be off for the other six public holidays and over the Christmas break. It was noted that an increase in the number of non-production days could assist with maintenance at the mine. Mining employees each worked approximately 180 shifts per year, including training and leave, and around 107 days excluding training and leave days.

During the 11.5-hour shift, time spent at the face ranged from 8 to 11.5 hours, and incorporated at least two of the following activities: drilling (approx. 4.2 hours); charging and blasting (aprox. 2.5 hours); support (approx. 5.2 hours); and loading (approx. 3.4 hours). Two blasts were planned per day, but sometimes only one blast was possible. The re-entry period was around 1 hour and was relatively short because of the long travelling times and as the working place was not confined. The time taken for workers to travel from the lamp room to the workplace was approximately 1 hour. The horizontal travelling distances to the workplaces were up to $2 \mathrm{~km}$, and the workers either walked or used trains to travel underground. Problems booked at the mine for the year to date were assessed, the majority of which related to support, and also included those relating to services and breakdowns. Contingency plans were in place in terms of labour, equipment, and power at the mine. Additional labour was planned for certain occupations in production. The planned contingency was around $15 \%$ per section, and an extra roving crew was available.

Most of the workers were reported to live within a $15 \mathrm{~km}$ radius of the mine. Workers used a range of transport modes to commute, including public transport, private vehicles, and mine buses (for those living in the mine hostel). The working hours were adjusted to accommodate for public transport availability. It was estimated that workers could spend approximately 10 hours at home on workdays, when accounting for working hours and commuting times. It was reported that some of the workers lived in informal housing (shacks), and the poor living conditions associated with this housing could contribute to fatigue. In addition to the long shifts worked, commuting times, and living conditions the high temperatures in the mine were a potential contributor to fatigue. Fatigue management programmes, processes, and training, wellness programmes, and mid-shift meal breaks were in place.

The fatality frequency rate was 0.00 and the lost-time injury rate was 1.20 for 2019 (at the time of the data collation), compared the rates from the previous year of 0.05 and 0.98 , respectively. The absenteeism rate at the mine for all causes was $16 \%$ for the year to date, and was considered by mine management to be reasonable, compared to other mines. Absenteeism comprised approximately 43\% annual leave, 24\% training, $14 \%$ sick leave, 3\% 'absent', and 16\% 'other'. 


\section{Optimization of shift cycles in the South African mining sector}

\section{Fatigue and risk indices}

The HSE fatigue calculator was used to estimate and compare fatigue and incident/accident risk for different shift rosters. Three shift rosters were chosen as examples, and the results are shown in Figures 1 to 3. Fatigue and risk scores are provided for each shift within a schedule. The fatigue and risk indices are similar in many respects, but differences include time-of-day effects (e.g. accident risk tends to be higher close to midnight, while fatigue tends to peak in the early morning). The fatigue scores range from zero to 100 and indicate the percentage chance of experiencing high levels of sleepiness, such that the workers might struggle to stay awake during that shift. Meanwhile, the risk scores refer to the relative risk of an accident or incident, with a baseline value of 1.0 .
The default scores of the index can be adjusted according to commuting times, job types, and job breaks components. For this analysis, the default scores were kept consistent, and were set at 1 hour commuting time, a moderately demanding workload, mostly continuous attention requirement, and rest breaks taken for 30 minutes after every 5.5 hours, and for 5 minutes every 2 hours. Changes in these components, and in shift start and end times, have significant impacts on the fatigue and incident risk scores. The tool is useful for assessing risks of fatigue and injury, but should not be relied on as the primary means of assessing these risks, and does not account for factors such as specific work-related issues, individual differences, or social factors that might affect workers' tolerance to shift work (HSE, 2019).

It is evident that the scores, particularly for fatigue, are higher during night shifts than during day shifts. Additionally,

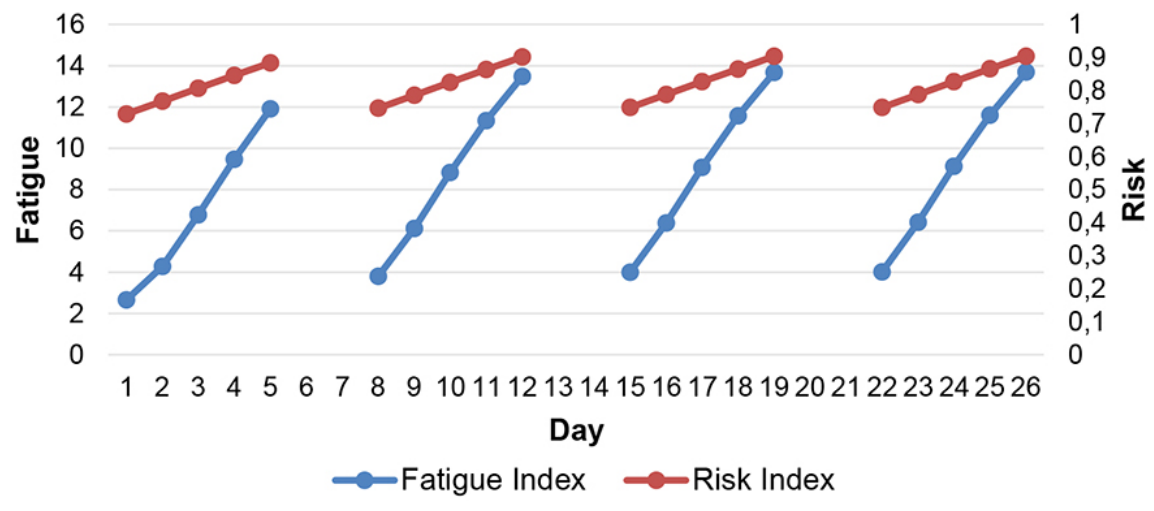

Figure 1-Fatigue and accident risk of a 5D 20 (day shift only) cycle with 8-hour 40-minute shifts (starting at $07 \mathrm{~h} 00$ and ending at 15h40)

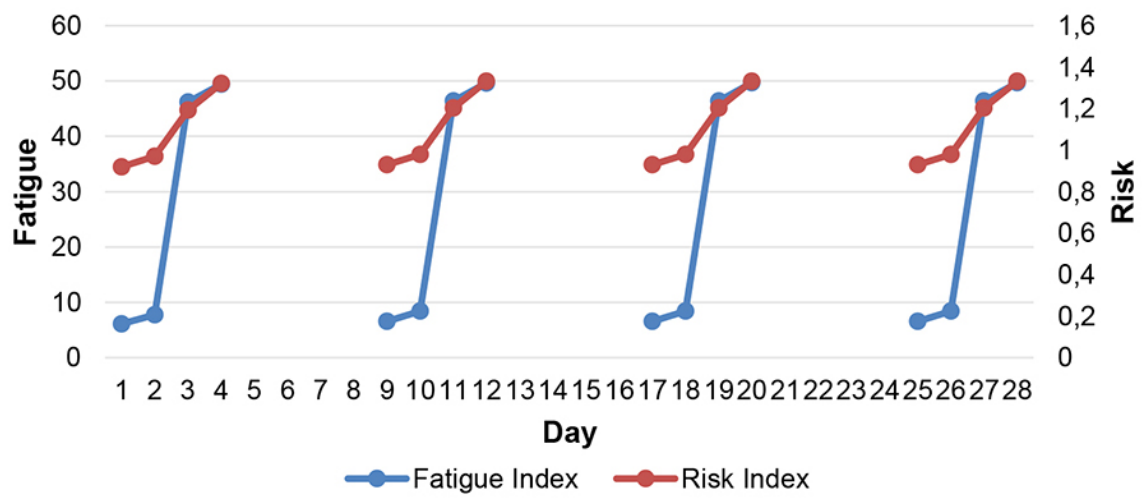

Figure 2-Fatigue and accident risk of 2D 2N 40 cONOPs cycle with 12-hour shifts, starting and ending at $07 \mathrm{~h} 00$ and $19 \mathrm{~h} 00$ (day shift) and $19 \mathrm{~h} 00$ and $07 \mathrm{~h} 00$ (night shift)

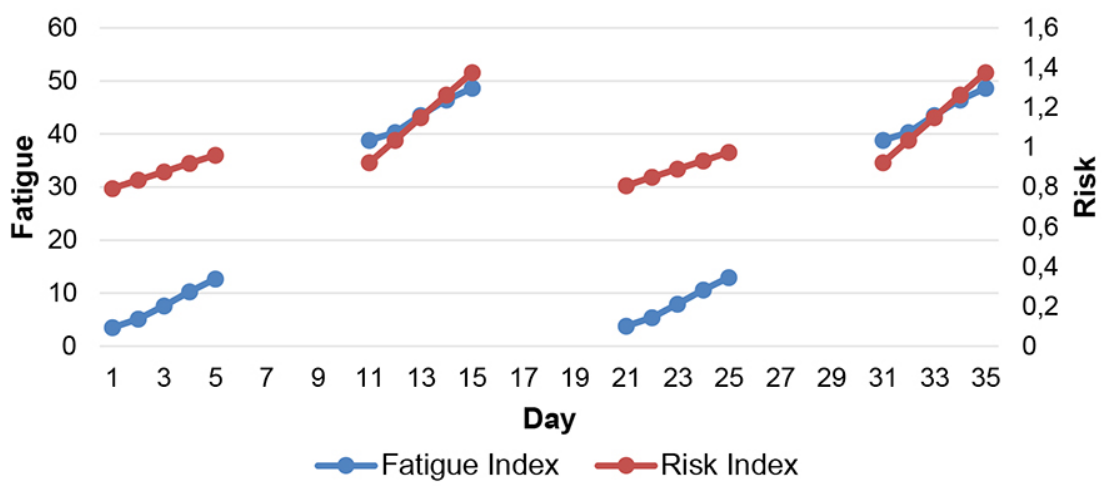

Figure 3-Fatigue and accident risk of a 5D 5N 50 cONOPs cycle with 10-hour shifts, starting and ending at $07 \mathrm{~h} 00$ and $15 \mathrm{~h} 00$ (day shift) and $20 \mathrm{~h} 00$ and $06 \mathrm{~h} 00$ (night shifts) 


\section{Optimization of shift cycles in the South African mining sector}

the fatigue and accident risks increase with the number of consecutive shifts worked. Meanwhile, the days off provide an opportunity for recovery in between shifts worked. If fatigue and accident risk scores do not return to the original values when the shift cycle is repeated, it indicates that workers do not have the opportunity to fully recover within the shift cycle. Higher fatigue and accident scores were evident for the rosters with longer shift lengths, while lowest risk scores were evident in the rosters that only incorporated day shifts.

\section{Discussion and recommendations}

The case studies provide examples of the successful implementation of CONOPs at mines in South Africa. The main benefit of CONOPs that was indicated was improved productivity (in terms of the number of tons produced per month), as the longer shifts helped to increase face times in relation to the total number of hours worked. This finding is in support of the literature on the topic; for example, Stenzel (2002) reported that the productivity of a certain mine increased by $21 \%$ after implementation of CONOPs with a 12-hour shift roster. Additionally, maintenance was improved, as service shifts were incorporated into the rosters. The use of contingency measures such as availability of spare panels and extra roving crews further aided continued production. However, potential challenges associated with longer shifts included increased fatigue and absenteeism. Other factors that were associated with fatigue and OHS outcomes during shift work included commuting times, living conditions, the provision of meal breaks and mid-shift meals, the workplace environmental conditions (e.g. heat), and job demands. Analysis of the fatigue and accident risks associated with selected rosters revealed that the risks were higher with longer shifts, during night shifts, and when numerous consecutive shifts were worked. The implementation of CONOPs might differ between the case study sites and conventional mining operations in some respects; however, the basic principles relating to the use of CONOPs could be applied to different types of mining operations.

A draft framework was compiled based on the findings from the literature review and research conducted, and was discussed and amended based on feedback received from the technical workshop. The draft framework serves as a basis for further industry engagement and recommended research for the optimization of shift cycles in the South African mining industry. The framework includes numerous considerations and recommendations relating to shift cycle design, which are summarized in Table II.

It is evident that the ideal shift rostering system for the mining sector must holistically consider and balance operational requirements, employee needs, and OHS requirements. The assessment of shift cycles and fatigue should consider a number of factors, and be developed to suit the unique needs of each operation. Consultation between stakeholders, including mining companies and worker representatives, is important for the successful implementation of changes to shift cycles.

The development and implementation of new shift schedules will require a structured change management process and effective stakeholder engagement. For example, the PlanDo-Check-Act (PDCA) model can be used to plan, develop, implement, and continually improve the new shift roster. This project links to work conducted in the Successful Application of Technology Centred Around People (SATCAP) programme, which aimed to identify appropriate change management and stakeholder engagement processes for shift cycles appropriate for mine modernization. The Mining Industry Occupational Safety and Health (MOSH) adoption process for leading practices could be used to facilitate the implementation of new shift schedules.

Recommendations for future research needs were identified during the project. Primarily, the need for involvement of further stakeholders, including representatives from a range of mines, labour representatives from each union, and government and community representatives, was emphasised for the finalization of guidelines for shift cycle optimization in the South African mining sector. Qualitative research involving mineworkers was recommended. In addition, participation from members involved with the Sindisa Gold Project was suggested to build on this work. Further research could involve additional analyses of the processes that have been used by mines when successfully implementing changes to shift cycles. Additional input relating to occupational medicine impacts of different shifts would be helpful to refine the shift cycle framework. An assessment of best and worst practices relating to shift cycles, and available monitoring systems and tools, would be valuable, along with the development of a toolbox for monitoring and evaluation of performance. Research involving the use of real-time information management and monitoring systems, such as smart watches, was also recommended. Further suggested work relates to reward systems or remuneration practices, the ageing workforce, resistance to change, and workplace culture in the modernizing South African mining industry. In addition, a systems approach, integrating work conducted within the LoCM and broader SAMERDI projects, is suggested, as many of the findings could be related for appropriate implementation in the mining sector.

\section{Conclusion}

Changes to shift cycles could help to enhance the viability of the South African mining sector. These changes could help to address challenges relating to increased travelling times, reduced face times, and impaired productivity, while addressing the impact of commuting times, personal factors, and worker fatigue in relation to shift work. This paper outlined several factors to consider when assessing shift cycle options. Operational and productivity requirements, OHS matters, and employee preferences need to be taken into account. Furthermore, stakeholder engagement and change processes need to be effectively managed. Additional research, involving a broader range of stakeholders, will assist in the completion of guidelines for shift cycle optimization in the South African mining sector.

\section{Acknowledgements}

This project was funded by the Minerals Council South Africa (MCSA) and commissioned by the Mandela Mining Precinct. The Mandela Mining Precinct is a public-private partnership between the Department of Science and Innovation and the MCSA. The Precinct is co-hosted by the CSIR and the MCSA. We would like to acknowledge Martin Pretorius in the role of LoCM Programme Manager. We also thank Sophi Hlatshwayo, Zintle Nontso, and Refiloe Maponya for their contributions. Finally, we are grateful to the mines and individuals who participated in this research.

\section{References}

ALjuHAnI, M. 2002. Labour's utilisation and labour's productivity of a gold mine in Saudi Arabia. Journal of the Southern African Institute of Mining and Metallurgy, vol. 102, no. 5. pp 307-310. 


\section{Optimization of shift cycles in the South African mining sector}

\begin{tabular}{|c|c|c|c|}
\hline $\begin{array}{l}\text { Shift roster } \\
\text { element }\end{array}$ & Category & Description & Recommendation \\
\hline \multirow[t]{11}{*}{$\begin{array}{l}\text { Understanding shift } \\
\text { rosters }\end{array}$} & Shift cycles & $\begin{array}{l}\text { Assess various shift } \\
\text { rosters, taking into } \\
\text { consideration all the key } \\
\text { shift roster design } \\
\text { parameters }\end{array}$ & - Do a cost benefit analysis of different shift lengths and schedules \\
\hline & $\begin{array}{l}\text { Legal requirements } \\
\text { and company } \\
\text { standards }\end{array}$ & $\begin{array}{l}\text { - Ensure compliance of the } \\
\text { selected shift roster to all } \\
\text { applicable legislation }\end{array}$ & $\begin{array}{l}\text { - If the shift roster does not comply to certain provisions of the legislation consider the following: } \\
\text { - Aligning the shift roster to legislation } \\
\text { Blasting alternative shift rosters } \\
\text { - Requesting for exemptions from the responsible authorities }\end{array}$ \\
\hline & $\begin{array}{l}\text { Understand the gaps } \\
\text { of the current shift } \\
\text { roster }\end{array}$ & $\begin{array}{l}\text { - Understand major } \\
\text { constraints within the } \\
\text { current shift roster }\end{array}$ & - Do a detailed analysis of major constraints and suggest suitable interventions \\
\hline & $\begin{array}{l}\text { Define the goals and } \\
\text { key performance } \\
\text { indicators (KPIs) }\end{array}$ & $\begin{array}{l}\text { From the identified } \\
\text { constraints, define goals } \\
\text { and KPls which will be } \\
\text { achieved by changing the } \\
\text { shift roster }\end{array}$ & - Develop specific, measurable, attainable, relevant, and time-bound (SMART) goals and KPIs \\
\hline & $\begin{array}{l}\text { Determine the labour } \\
\text { requirements }\end{array}$ & $\begin{array}{l}\text { Determine the human } \\
\text { resource requirements of } \\
\text { the shift roster options }\end{array}$ & $\begin{array}{l}\text { - Labour requirements should be informed by the workload and practical evidence from time motion studies } \\
\text { - Ensure the availability of the right expertise at the right work place and right time } \\
\text { - Avail at least one supervisor with the necessary expertise, to oversee all operational activities on every shift }\end{array}$ \\
\hline & $\begin{array}{l}\text { Enhancing } \\
\text { effectiveness and } \\
\text { utilisation of labour }\end{array}$ & $\begin{array}{l}\text { Put in place measures to } \\
\text { maximise the effectiveness } \\
\text { and utilisation of labour on } \\
\text { all shifts }\end{array}$ & $\begin{array}{l}\text { - Effective supervision } \\
\text { - Avail at least one supervisor with the necessary expertise, to oversee all operational activities on every shift } \\
\text { ofe real-time information management systems (RTIMS) to improve the effectiveness of supervision, utilisation } \\
\text { - Effective training to improvectision-making } \\
\text { - Focus on improving team morale and cultivating a high performance work culture } \\
\text { - Promote team works and use of self-directed work teams (SDWT) } \\
\text { - Ensure effective communication at all levels within the organisation }\end{array}$ \\
\hline & Shift length & $\begin{array}{l}\text { - Determine the correct shift } \\
\text { length }\end{array}$ & $\begin{array}{l}\text { - Shift length should be determined taking cognisance of factors such as work requirements, travelling time, OHS } \\
\text { requirements and workplace conditions }\end{array}$ \\
\hline & Support services & $\begin{array}{l}\text { Provide sufficient support } \\
\text { services to ensure asset } \\
\text { integrity and optimum } \\
\text { utilisation of equipment }\end{array}$ & $\begin{array}{l}\text { - Having maintenance crews operating on all mining shifts } \\
\text { - Use of cross-trained operator-maintenance artisans } \\
\text { - Echeduling most of the maintenance tasks during day shift } \\
\text { arrangements }\end{array}$ \\
\hline & $\begin{array}{l}\text { Optimise the utilisation } \\
\text { of equipment }\end{array}$ & $\begin{array}{l}\text { - Ensure optimum utilisation } \\
\text { of mine equipment }\end{array}$ & - Mines must strive to operate continuously (i.e., 365 days a year, 7 days a week and 24 hours a day) \\
\hline & $\begin{array}{l}\text { Ore reserve } \\
\text { availability }\end{array}$ & $\begin{array}{l}\text { - Ensure availability of } \\
\text { ground to mine all the time }\end{array}$ & $\begin{array}{l}\text { - Maintain a minimum of } 18 \text { months ore availability period (Sebutsoe and Musingwini, 2017). } \\
\text { - Investigate the use of accelerated ore reserve development technologies }\end{array}$ \\
\hline & $\begin{array}{l}\text { Logistics and } \\
\text { inventory control }\end{array}$ & $\begin{array}{l}\text { - Ensure an efficient logistics } \\
\text { and inventory control } \\
\text { system }\end{array}$ & $\begin{array}{l}\text { - Use of underground buffer stores utilising scanning technologies for controlling inventory levels } \\
\text { - Use of asset tracking } \\
\text { - Investigate alternative efficient transportation systems }\end{array}$ \\
\hline \multirow[t]{8}{*}{$\begin{array}{l}\text { OHS requirements } \\
\text { and employee needs }\end{array}$} & Fatigue & $\begin{array}{l}\text { - Design shift schedule } \\
\text { optimally to reduce the risk } \\
\text { of fatigue }\end{array}$ & $\begin{array}{l}\text { - Overtime and on-call work should be limited } \\
\text { - Avoid backward rotating shifts (e.g. night to afternoon to morning) } \\
\text { - Avoid shift rosters with irregular or unpredictable patterns } \\
\text { - Provide at least } 36 \text { hours off following a period of night shift work } \\
\text { - Fatigue management programmes should address the unique conditions of each operation } \\
\text { - Implement systems or technology to monitor performance of workers in safety-critical positions }\end{array}$ \\
\hline & $\begin{array}{l}\text { Occupational health } \\
\text { and wellness }\end{array}$ & $\begin{array}{l}\text { - Manage the health and } \\
\text { occupational exposures of } \\
\text { workers }\end{array}$ & $\begin{array}{l}\text { - Occupational exposures are affected by shift lengths and should be managed accordingly, such as for } \\
\text { radiation, silicosis, diesel particulate matter, and thermal strain. } \\
\text { - Medical conditions and psychological issues are associated with fatigue, and should be managed in the context of } \\
\text { shift work } \\
\text { - Workers should be able to eat properly, participate in recreational exercise, and be educated about lifestyle factors } \\
\text { that can affect their health (e.g. smoking and substance abuse) }\end{array}$ \\
\hline & Working conditions & $\begin{array}{l}\text { - Assess working conditions } \\
\text { to minimise health, safety } \\
\text { and fatigue risks }\end{array}$ & $\begin{array}{l}\text { - Safety critical tasks should not be undertaken when employees are likely to be fatigued (e.g. during night shifts, } \\
\text { 12-hour shifts, or when performing work with high physical or mental demands, or repetitive or monotonous work) } \\
\text { - Ensure appropriate rest breaks within each shift } \\
\text { - Poor nutrition contributes to fatigue, therefore consider the supply of meals or supplements for workers; } \\
\text { the impact of restrictions due to illegal mining should also be considered } \\
\text { - Ensure availability of drinking water } \\
\text { - Work environment factors such as lighting, noise, vibration, and temperature should be appropriate for worker } \\
\text { health, safety, and comfort } \\
\text { - Appropriate management services should be available to those working outside of ordinary hours } \\
\text { - Ensure availability of appropriate resources e.g. staffing and equipment }\end{array}$ \\
\hline & Socioeconomic factors & $\begin{array}{l}\text { - Consider workers' financial } \\
\text { and living conditions }\end{array}$ & $\begin{array}{l}\text { - Consider the living conditions of workers, as aspects such as exposure to noise and temperature extremes } \\
\text { contributes to a lack of sleep and fatigue } \\
\text { - Financial wellness of workers should be considered }\end{array}$ \\
\hline & Commuting times & $\begin{array}{l}\text { Assess the length of time it } \\
\text { takes for workers to } \\
\text { commute to and home } \\
\text { from work }\end{array}$ & $\begin{array}{l}\text { - The total amount of time from when workers leave home before a work shift until returning home afterwards } \\
\text { should allow for continuous sleep of seven to eight hours in each } 24 \text {-hour period } \\
\text { - Consider the availability or provision of transport for workers } \\
\text { - Consider travel times of migrant workers to avoid high risk when travelling from or returning to work }\end{array}$ \\
\hline & $\begin{array}{l}\text { Social and domestic } \\
\text { responsibilities }\end{array}$ & $\begin{array}{l}\text { Ensure that workers have } \\
\text { sufficient time between } \\
\text { shifts to attend to personal } \\
\text { activities }\end{array}$ & $\begin{array}{l}\text { - Workers should have sufficient time each day to attend to daily responsibilities } \\
\text { - Workers should have time within their shift schedule to attend to family and social commitments, including } \\
\text { shopping or going to the bank } \\
\text { - Workers should have at least one weekend off per month }\end{array}$ \\
\hline & Worker preferences & $\begin{array}{l}\text { - Consider worker } \\
\text { preferences in shift } \\
\text { schedule design }\end{array}$ & $\begin{array}{l}\text { - Consider employee preferences and needs in shift schedule design } \\
\text { - Provide workers with information or training about shift work, and strategies to cope with irregular working hours } \\
\text { - Consult with workers before changes to shift cycles are made }\end{array}$ \\
\hline & $\begin{array}{l}\text { Stakeholder } \\
\text { engagement and } \\
\text { change processes }\end{array}$ & $\begin{array}{l}\text { Follow a structured change } \\
\text { management process, } \\
\text { which includes and } \\
\text { involves all stakeholders }\end{array}$ & $\begin{array}{l}\text { The following approach has been considered best practice for change management: } \\
: \text { Identify what will be changed/improved } \\
\text { : Pse an inclusive process to arrive at a solid business case } \\
\text { Provide resources and use data for evaluation } \\
\text { : Mnsure effective communication } \\
\text { - Relebrater and manage resistance, dependencies, and budgeting risks } \\
\text { Review, revise and continuously improve }\end{array}$ \\
\hline
\end{tabular}




\section{Optimization of shift cycles in the South African mining sector}

Baker, A., Heiler, K., and Ferguson, S.A. 2003. The impact of roster changes on absenteeism and incident frequency in an Australian coal mine. Journal of Occupational and Environmental Medicine, vol. 60. pp. 43-49.

Bates, D.W. 2009. Fatigue, resident work hours, and safety. Medical Care, vol. 47, no. 7, pp. 711-713.

Baulk, S.D., Fletcher, A., Kandelaars, K.J., Dawson, D., and Roach, G.D. 2009. A field study of sleep and fatigue in a regular rotating 12-h shift system. Applied Ergonomics, vol. 40, no. 4. pp. 694-698.

BRAKE, D.J. 2015. A review of good practice standards and re-entry procedures after blasting and gas detection generally in underground hardrock mines. Proceedings of the 15th North American Mine Ventilation Symposium, Backsburg, VA. Virginia Tech.

Brovko, F., Kgarume, T., Maseka, C., Sereme, B., and Ngobese, S. 2018. Work package 1: Detailed gap analysis and recommendation for process improvement of mining cycle elements of conventional gold and platinum operations in orde to design a system to enable a blast per day that confirms to mine standard (Appendix A). 2018. Technical LoCM Close-Out Report for the Period 2017/2018. Gumbie, A. (ed.). Longevity of Current Mines Programme. Mandela Mining Precinct, Johannesburg. Unpublished report.

Brown, M., Tucker, P., Rapport, F., Hutchings, H., Dahlgren, A., Davies, G., and Ebden, P. 2010. The impact of shift patterns on junior doctors' perceptions of fatigue, training, work/life balance and the role of social support. Quality Safety Health Care, vol. 19, no. 6. pp. 1-4.

DeLortTe. 2014. The future of mining in South Africa: Innovation imperative. https:// www2.deloitte.com/content/dam/Deloitte/za/Documents/energy-resources/ ZA_Mine_of_the_Future_06022015.pdf [accessed 18 July 2018].

Department of Labour. 1993. Occupational Health and Safety Act. Act No. 85 of 1993. Republic of South Africa.

Department of Labour. 1997. Basic Conditions of Employment Act. Act No. 75 of 1997. Republic of South Africa.

Department of Labour. 1998. Code of Good Practice on the Arrangement of Working Time. Republic of South Africa.

Department of Mineral Resources. 1996. Mine Health and Safety Act. Act No. 29 of 1996. Republic of South Africa.

Department of Mineral Resources. 2014. Guideline for a Mandatory Code of Practice for Risk-Based Fatigue Management at Mines. Republic of South Africa.

Greubel, J., Arlinghaus, A., Nachreiner, F., and Lombardi, D.A. 2016. Higher risks when working unusual times? A cross-validation of the effects on safety, health, and work-life balance. International Archives of Occupational and Environmental Health, vol. 89, no. 8. pp. 1205-1214.

Gumbie, A. 2018. Technical LoCM Close-Out Report for the Period - 2017/2018. Longevity of Current Mines Programme. Mandela Mining Precinct, Johannesburg. Unpublished report.

Härmä, M., Karhula, K., Ropponen, A., Puttonen, S., Koskinen, A., Ojajärvi, A., Hakola, T., Pentti, J., Oksanen, T., Vahtera, J., and Kivimäki, M. 2018. Association of changes in work shifts and shift intensity with change in fatigue and disturbed sleep: a within-subject study. Scandinavian Journal of Work, Environment and Health, vol. 44, no. 4. pp. 394-402.

Health and Safety Executive (HSE). 2019. The development of a fatigue / risk index for shiftworkers. https://www.hse.gov.uk/research/rrhtm/rr446.htm\# [accessed 13 September 2019].

Hodgskiss, J., Letsoalo, S., April, Y., and Schutte, S. 2015. Health and safety impacts of socioeconomic conditions and other matters relating to living conditions in the South African mining industry. Project no. SIM 13-09-01. Mine Health and Safety Council.

Jacobs, J. and WebBer-Youngman, R.C.W. 2017. A technology map to facilitate the process of mine modernization throughout the mining cycle. Journal of the Southern African Institute of Mining and Metallurgy, vol. 117, no. 7. pp. 637-648.

JacoBsen, D.I. and FJelLDBRAaten, E.M. 2018. Shift work and sickness absence-the mediating roles of work-home conflict and perceived health. Human Resources Management, vol. 57, no. 5. pp. 1145-1157.

Kalmbach, D.A., Fang, Y., Arnedt, T., Cochran, A.L., Deldin, P.J., Kaplin, A.I., and Sen, S. 2018. Effects of sleep, physical activity, and shift work on daily mood: a prospective mobile monitoring study of medical interns. Journal of General Internal Medicine, vol. 33, no. 6. pp. 914-920.

LAZARE, R. 2013. SA Region Shift Optimisation-SVP Review. Unpublished report. Minerals Councll South Africa. 2018. Modernization: Towards the mine of tomorrow. Fact Sheet. http://www.mineralscouncil.org.za/industry-news/publications/factsheets/send/3-fact-sheets/378-modernisation-towards-the-mine-of-tomorrow [accessed 18 July 2018].
NeIngo, P.N. and CAWood, F.T. 2014. Correlation of productivity trends with market factors at three selected platinum mines. Proceedings of the 6th International Platinum Conference, 'Platinum - Metal for the Future', Sun City, South Africa, 20-22 October 2014. Southern African Institute of Mining and Metallurgy, Johannesburg. pp. 181-188.

Neingo, P.N. and Tholana, T. 2016. Trends in productivity in the South African gold mining industry. Proceedings of the 23rd Internal Symposium on Mine Planning and Equipment Selection (MPES) 2016, Sandton Convention Centre, Johannesburg, 8-11 November 2016. Southern African Institute of Mining and Metallurgy, Johannesburg.

NGOBESE, S. 2017. Comparison of different shift rosters. CSIR, Pretoria. Unpublished report.

Pelders, J. and Nelson, G. 2019. Contributors to fatigue at a platinum smelter in South Africa. Journal of the Southern African Institute for Mining and Metallurgy, vol. 119, no. 3. pp. 313-319.

Pelders (Hodgskiss), J., Magweregwede, F., Maponya, R., Rupprecht, S.M., Hlatshwayo (Letsoalo), S., Nontso, Z., and Brovko, F. 2019. Shift cycles and productivity. Milestone 8: Final Report. Longevity of Current Mines Programme. Mandela Mining Precinct, Johannesburg. Unpublished report.

Pfeifer, C. 2017. An empirical note on commuting distance and sleep during workweek and weekend. Bulletin of Economic Research, vol. 70, no. 1. pp. $97-102$.

Pickering, R., du Plessis, A., and Annandale, G. 2010. Hard-rock room and pillar mining best practice industry workshop. Report no. 01010-01. Centre for Mechanised Mining Systems, University of the Witwatersrand.

Roussos, M. 1996. Productivity barriers in the mining industry. MBA thesis, School of Business Administration, University of the Witwatersrand.

Rupprecht, S.M., Wilson, R.B., Lombard, H.E. and PeAKe, A.V. 2001. Transportation summary. DEEPMINE Collaborative Research Programme. March 2001.

RupPRECHT, S.M. 2016. The need for material change in the South African mining industry. New technology and innovation in the Minerals Industry Colloquium, Emperor's Palace, 9-10 June 2016. Southern African Institute of Mining and Metallurgy, Johannesburg.

Rupprecht, S.M. 2018a. A move to a 12-hour working shift - The benefits and concerns. Proceedings of the 27th International Symposium on Mine Planning and Equipment Selection, Santiago, Chile. 20-22 November 2018. Springer. pp. 545-552.

RuPPRECHT, S.M. 2018b. Work Package 4: Ranking production related best practices based on current mining process and equipment available (Appendix E). Technical LoCM Close-Out Report for the Period - 2017/2018. Gumbie, A. (ed.). Longevity of Current Mines Programme. Mandela Mining Precinct, Johannesburg. Unpublished report.

SANQU, A. 2016. An address on industry productivity: How bad (or good) are we really? Joburg Indaba, 5 October 2016. Chamber of Mines of South Africa.

SchutTe, P.C. 2010a. Fatigue risk management: Charting a path to a safer workplace. Journal of the Southern African Institute of Mining and Metallurgy, vol. 110, pp. 53-55.

SchuTTE, P. 2010b. Heat stress management in hot mines. Extracting the Science: A Century of Mining Research. Brune, J.F. (ed.). Society for Mining, Metallurgy, and Exploration, Inc., Littleton, CO. pp. 30-34.

Sebutsoe, T. and Musingwinl, C. 2017. Characterizing a mining production system for decision-making purposes in a platinum mine. Journal of the Southern African Institute of Mining and Metallurgy, vol. 112, no. 2. pp.199-206.

Singh, N. 2017. Weathering the 'perfect storm' facing the mining sector. The Journal of the Southern African Institute of Mining and Metallurgy, vol. 117, no. 3. pp. 223-229.

Smith, L., Folkard, S., Tucker, P., and Macdonald, I. 1998. Work shift duration: a review comparing eight hour and 12 hour shift systems. Journal of Occupational Environmental Medicine, vol. 55, no. 4. pp. 217-229.

Spencer, M.B., Robertson, K.A., and FolKard, S. 2006. The development of a fatigue / risk index for shiftworkers. Research report no. 446. Mine Health and Safety Executive.

STENZEL, G.G. 2002. Introduction of 12 hour shift and 4 x4 roster working 24/7 at New Vaal Colliery. Colliery SACMA Meeting. Presentation at Goedehoop South African Colliery Managers Association.

THERon, W.J. 2014. Fatigue knowledge - A safety management imperative. AMMSA Safety General Meeting. Association of Mine Managers South Africa.

Van Ommeren, J. and Gutierrez-I-Puigarnau, E. 2009. Are workers with a long commute less productive? An empirical analysis of absenteeism. Tinbergen Institute Discussion Paper. no. 09-014/3. Tinbergen Institute, Amsterdam. 